\title{
SECONDARY SEX RATIO IN A SOUTH-WESTERN NIGERIAN TOWN
}

\section{TOLULOPE OYENIYI}

Department of Biological Sciences, College of Science, Engineering and Technology, Osun State University, Osogbo, Osun State, Nigeria. ${ }^{*}$ Corresponding Author: Email- totalege@uniosun.edu.ng

Received: July 30, 2012; Accepted: August 06, 2012

\begin{abstract}
In this study, the human secondary sex ratio (described as the number of males per 100 female births) in Ondo, a town in South -West Nigeria was analyzed using birth record between 2001 and 2008, obtained at State Specialist Hospital. The analysis of the 11,426 births recorded during the period revealed a secondary sex ratio of 1.14, that is, 114 boys for every 100 girls born. There was a strong correlation $\left(0.236^{* *}\right)$ between sex ratio and birth outcome indicating that gender has strong influence on child survival. There is however no significant relationship between the sex of baby and the season of birth as the ratio of male to female babies remains unchanged through the seasons. This study reports the first information on secondary sex ratio in Ondo town and gives impetus for further investigations into factors affecting secondary sex ratio among the populations at the study area.
\end{abstract}

Key words- human secondary sex ratio, birth outcome, seasonality, Nigeria

Citation: Tolulope Oyeniyi (2012) Secondary Sex Ratio in a South-Western Nigerian Town. International Journal of Genetics, ISSN: 09752862 \& E-ISSN: 0975-9158, Volume 4, Issue 3, pp.-92-94.

Copyright: Copyright@2012 Tolulope Oyeniyi. This is an open-access article distributed under the terms of the Creative Commons Attribution License, which permits unrestricted use, distribution and reproduction in any medium, provided the original author and source are credited.

\section{Introduction}

Animals have demonstrated significant variations in the proportion of male to female that are born, even though individuals expend approximately equal efforts on male and female reproductive functions [1]. The mechanisms underlying these differences are unclear. Sex ratio is a general term for the number of females per 100 males; the secondary sex ratio (SSR) is the ratio of male to female at birth [2] The sex chromosomes segregate equally during meiosis in males, therefore it is expected that the human sex ratio would be $1: 1$ [2]; but on the contrary, the values obtained from studies of human populations across the world show that the expectation is not universal owing to several reasons [3-7]. In the absence of manipulations, the sex ratio is remarkably consistent across human populations with an average of 105-107 male births for every 100 female births.

Reduced survivals of male progeny before and after birth is a general finding in mammals especially humans amongst whom malebiased age-specific morbidity and mortality remain prominent during conception, neonatal life and infancy, adolescence and adult life. Several environmental and demographic factors affect sex ratio distribution across human populations, these include; coital frequency $[8,9]$ birth order $[10,11]$ paternal age [12-14] maternal weight and diet [15-17], maternal age [18], hormones [19,20], polygyny, [9,21] latitude [19,21], war [20,22], exposure to environmental pollutants [23-28], illhealth [29,30], parity [31-33], seasonal variation $[34,35]$, religion $[36]$, race $[18,37,38]$ and sex selective abortions [6,39-41].
In this study, a longitudinal analysis of secondary sex ratio distribution among the Ondo town population of South-West Nigeria done with the view of documenting possible relationship between secondary sex ratio,_birth outcome and season of birth

\section{Materials and Method}

Ondo town located on Lat $7.09^{\circ}$ and Long $4.84^{\circ}$ it has a population of 236600 people, predominantly Yoruba ethnicity [42]. Although not essentially a sleepy town, it is not an industrial settlement as there is just a Cocoa- processing industry and a closed- down Wood industry. The maternity unit of the State Specialist Hospital, Ondo provides services for pregnant women from within and outside the town. At the time of the study, antenatal attendance at the hospital had increased owing to the State Government's free health care services for pregnant women and infants. The record of all deliveries from 1st January 2001 to 31 st Dec. 2008 was taken from the medical records unit of the hospital and data collected were: sex of baby, outcome of delivery- live/still birth and month of birth.

\section{Data Analysis}

Yearly secondary sex ratio was determined using the formula:

$$
X / Y \times 100
$$

where $x$ is no. of females and $y$ is no. of males. Pearson's correlation test was used to compare the relationship between live and still birth sex ratio and Student's t-test was used to examine seasonal variation in sex ratio of live births. All data were analyzed using SPSS version 15.0. 


\section{Results}

Analysis of the 11,426 births as shown in table 1 below revealed a secondary sex ratio of 1.14 in Ondo town that is, 114 boys for every 100 girls at birth. It was observed that the highest (1.28) and lowest (1.01) sex ratio was recorded in the year 2006 and 2001 respectively (Fig. 1). Coincidentally, it was also noted that the year 2006 had the lowest (979) total birth. This confirms that the sex ratio values were not influenced by the annual birth total. Through out the period considered, the sex ratio was fluctuating and had no definite pattern.

Table 1- Secondary sex ratio of total birth recorded for the eight year period (2001-2008)

\begin{tabular}{|lllll|} 
Year & $\begin{array}{l}\text { No. of Male } \\
\text { births }\end{array}$ & $\begin{array}{l}\text { No. of Female } \\
\text { births }\end{array}$ & $\begin{array}{l}\text { Total No. of } \\
\text { births }\end{array}$ & Sex Ratio \\
\hline 2001 & 765 & 759 & 1524 & 1.01 \\
2002 & 778 & 687 & 1465 & 1.19 \\
2003 & 839 & 734 & 1573 & 1.15 \\
2004 & 866 & 771 & 1637 & 1.12 \\
2005 & 719 & 641 & 1360 & 1.16 \\
2006 & 529 & 450 & 979 & 1.28 \\
2007 & 743 & 721 & 1464 & 1.08 \\
2008 & 744 & 680 & 1424 & 1.13 \\
Overall Total & 5983 & 5443 & 11426 & 1.14 \\
\hline
\end{tabular}

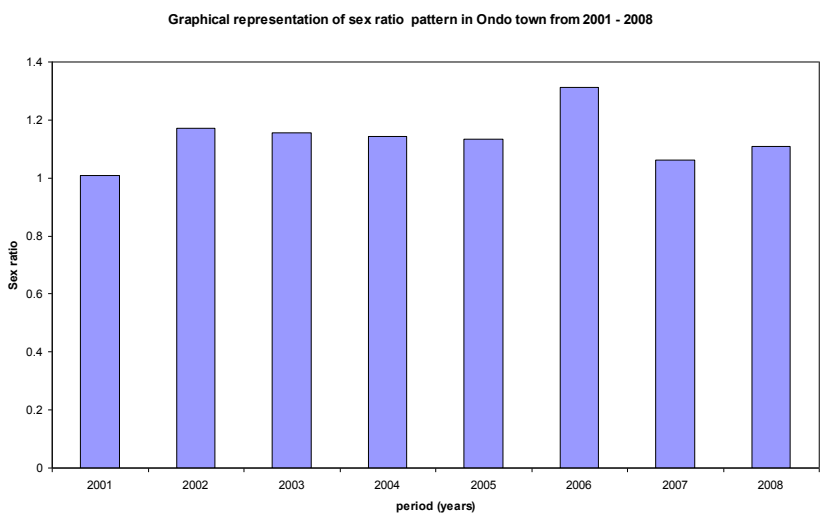

Fig. 1- Secondary sex ratio distribution in Ondo town showing the highest and the lowest

A comparison of the sex ratio of live and still birth showed a strong correlation $\left(0.236^{* *}\right)$ as mortality was higher in male babies; this implies that gender has a strong influence on a baby's survival. On the other hand, comparison of sex ratio in the dry and rainy seasons $(0.774$ at $\mathrm{P}>0.05)$ revealed no significant relationship between sex of baby and season of birth, the ratio of male to female babies remains unchanged through the seasons.

\section{Discussion}

The secondary sex ratio in the population under study was 114:110; a value higher than those reported for South-West Yoruba populations. There is a strong correlation $\left(0.236^{* *}\right)$ between the sex ratio and birth outcome, more males were stillborn. A comparison of sex of baby and season of birth (Rainy versus Dry Seasons) indicated that there is no relationship between season of birth and sex of baby.

Ondo town and its immediate environs are a relatively virgin land with respect to industrialization; a cocoa processing factory and the defunct Nigerian-Romanian wood industry are the only industries present. This could mean that activities generating environmental pollution from industrialization are minimal or nearly absent. Although commercial activities of privately owned businesses which are mostly small-scale are very common, the main means of livelihood is civil service-derived. It is worth noting that sex selective abortions could not be a common practice in the not-soindustrialised town. These findings suggest an association between the sex ratio and the environment. If low secondary sex ratios have been observed in human populations living in heavily polluted areas $[24-28,43,44]$ then a high sex ratio in a population such as the one under study may be an indicator of the state of environmental health, in this case, the environment is seen as one which has no history of natural or man-made disasters, therefore it can be deemed relatively unpolluted. The human secondary sex ratio has not only been suggested to be a non-invasive monitor of reproductive health in populations, changes in the secondary sex ratio especially of populations can be used as indicators of altered reproduction which might have been initiated by environmental factors.

The findings of this study suggest a higher ratio for males than females at birth in Ondo and are consistent with several reports around the world-number of males at birth exceeds that of females in un-affected populations [6,41]. The ratio is greater than the annual sex ratio of 104:100 for the Igbos of the South-East [45], 104:100 [46] to 107:100 [36] for the old Western States of Nigeria, 108:100 for Ibadan [46] and 103: 100 average for selected towns in Osun State area of South-West Nigeria [7].

It is however close to the 107-112:100 reported in Northern Nigeria $[48,49]$ but greater than the 106:100 reported in several other Black populations $[6,18,21]$ and in some Asian populations $[41,50]$.

The correlation found between mortality and sex ratio of males indicates that male babies are more susceptible to antenatal and peri-natal deaths and corroborates the reports of McMillen [51], Drevenstedt, et al. [52], Torche and Kleinhaus [53], it is however contrary to that of Halder and Fauzdar [49] reported low sex ratio in recurrent spontaneous abortuses.

On seasonality, the result is consistent with those of Lyster, [34] and Nonaka, et al. [35] who suggested that secondary sex ratio would be affected, if a significant proportion of conception is lost in a particular season in a manner that depends on foetal sex. However, the result of this investigation is contrary to that of Mosuro [47] and Cagnacci, et al. [16] who all reported seasonality in secondary sex ratio (in mothers or babies) across various populations.

Secondary sex ratio in Ondo town is higher than those recorded for other Yoruba populations. This may be due to several extrinsic; (demographic and environmental) and intrinsic (parental hormones, state of health and age) factors; further investigations elucidating the direct factors influencing the reportedly high secondary sex ratio in this population will be conducted in the nearest future.

\section{Acknowledgements}

The author is grateful to the authorities of the State Specialist Hospital, Ondo, Nigeria, the Chief Medical Director of the Hospital in person of Dr Ayo Adiji, and the records officer Mr Ikubolaje for their assistance during the collection of the data. 


\section{References}

[1] Rosenfeld C. and Roberts M. (2004) Biology of Reproduction 71, 1063-1070.

[2] Fisher R. (1930) New York: Dover, 1957.

[3] Gini C. (1955): Metron 17 (3-4), 1-41.

[4] James W.H. (1997a) Reprod. Toxicol., 11, 893- 895.

[5] Halder A. and Fauzdar A. (2006) Ind. J. Med. Res., 124, 41-50.

[6] Hesketh T. and Xing Z.W. (2006) PNAS, 103(36), 1327113275.

[7] Azzez M.A., Akinboro A. and Bakare A.A. (2007) Ind. J. Hum. Genet., 13, 59-64.

[8] James W.H. (1997) Annals of Human Biology, 24(5), 403-409.

[9] Whiting J.W.M. (1993) American Anthropologist, 95(4).

[10]Martin J.F. (1994) Current Anthropology, 35, 255-280.

[11]Jacobsen R., Moller H. and Mouritsen A. (1999) Hum. Reprod., $14,3120-3125$.

[12]Novitski E. and Sandler L. (1956) Am. J. Hum. Genet., 21, 123131.

[13]Ruder A. (1985) Am. J. Hum. Genet., 37, 362-372.

[14]James W.H. (2004) Hum. Reprod., 19, 1250-1256.

[15]Trivers R.L. and Willard D.E. (1973) Science, 179, 90-92.

[16]Cagnacci A., Renzi A., Arangino S., Alessandrini C. and Volpe A. (2004) Hum. Repro., 19(2), 442-444.

[17]Bulik C.M., Von Holle A., Gendall K., Kveim Lie K., Hoffman E., Mo X. Torgersen L. and Reichborn-Kjennerud T. (2008): Acta. Obstet. Gynecol. Scand., 87(9), 979-981.

[18] Garrene M. (2008) Hum. Biol., 80(5).

[19]James W.H. (2001) J. Epidemiol. Community Health, 55, 847.

[20]James W.H. (2008) J. Theor. Biol. 255(2), 199-204.

[21]Navara K.J. (2009) Biology Letters.

[22]Ellis L. and Bonin S. (2004) Soc. Sci. Inf., 43, 115-122.

[23]Lyster W.R. (1981) Med. J. Aust., II, 151-152.

[24] Vartiainen T., Kartovaara L., Tuomisto J. (1999) Environmental Health Perspectives, 107(10), 815.

[25]Mocarelli P., Gerthouz P.M., Ferrari E., Patterson D.G., Kieszak S.M., Brambilla P., et. al. (2000) Lancet, 355, 1858-63.

[26]Tsutsumi O., Nippon Rinsho (2000) Japanese Journal of Clinical Medicine, 58, 2464-2468.

[27]Yang C.Y., Cheng B.H., Hsu T.Y., et al. (2000) Environ. Res., 83(33).

[28]Garry V.F., Holland S.E., Erickson L.L. and Burroughs B.L. (2003) J. Toxicol. Environ. Health., 66, 965-986.

[29]Chanazarian A. (1988) Soc. Biol., 35(3-4), 214-235.
[30]Gundy S., Babosa M., Baki M. and Bodrogi I. (2004) Pathol. Oncol. Res., 10, 197-203.

[31]MacMahon B. and Pugh T.F. (1953) Brit. J. Prev. Soc. Med., 7 83-86.

[32]Rostron J. and James W.H. (1977) Annals. Hum. Genet., 41, 205-217.

[33]Orvos H., Kozinsky Z. and Bartfai G. (2001) Hum. Reprod., 16, 803.

[34]Lyster W.R. (1971) Am. J. Obstet. Gynecol., 110, 1025-1028.

[35]Nonaka K., Desjardins B., Charbonneau H., Legare J., Miura T. (1998) Int. J. Biometeorol., 42, 89-92.

[36]Ayeni O. (1975) Annals of Human Biology, 2(2), 137-141.

[37]Ciocco A. (1938) Human Biology, 10, 36-64.

[38]Babay Z.A. ( 2004) Middle East Fertility Society Journal, 9(1), 66-69.

[39]Park C.B. and Cho N.H. (1995) Popul. Dev. Rev., 21, 59-84.

[40]Wu Z., Viisainen K. and Hemminki E. (2006) Reprod. Health Matters, 14, 172-80.

[41]Jha P., Kumar R., Vasa P., Dhingra N., Thirichelvam D., Moineddan R. (2006) Lancet, 367, 211-8.

[42]Tageo GPS City Index and Satellite Map 2006.

[43]Mackenzie C.A., Lockridge A. and Keith M. (2005) Environmental Health Perspectives, 113(10), 1295-1298.

[44]Saadat M., Ansari-Lari M. and Bahaoddini A. (2002) Occup. Environ. Med., 59, 853.

[45]Egwuatu V.E. (1984) International Journal of Gynaecology and Obstetrics., 22(5), 399-402.

[46]Boroffice R.A. (1979) Nig. J. Nat. Sci., 1, 99-102.

[47]Mosuro A.A. (1997) J. Sci. Res., 3, 113-117.

[48]Rehan N.E. (1982) British Journal of Obstetrics and Gynaecology, 89, 136-141.

[49]Sule S.T. and Madugu H.N. (2004) Annals of Human Biology 31(2), 258-262.

[50]Sheth S.S. (2006) Lancet, 367(9506), 185-186.

[51]Mcmillen M.M. (1979) Science, 6, 204(4388), 89-91.

[52]Drevenstedt G.L., Crimmins E.M., Vasunilashorn S. and Finch C.E. (2008) Proc. Natl. Acad. Sci. USA., 105(13), 5016-21.

[53]Torche F. and Kleinhaus K. (2011) Hum. Reprod., doi:10.1093/ humrep/der390. 